\title{
機能性消化管障害一診断・治療の進歩と今後 の展開
}

\author{
司 会 三浦総一郎 (防衛医科大学校内科) \\ 鳥居明 (鳥居内科クリニック (東京都) $)$ \\ 二神 生爾 (日本医科大学消化器内科) \\ 水上健（国立病院機構久里浜医療センター内視鏡部） \\ (発言順)
}

\section{機能性消化管障害の診断の進め方一診断の 手始めに}

三浦 本日は, 臨床の現場で大変話題になっ ております機能性消化管障害というテーマで, いろいろとお話を伺いたいと思います。機能性 消化管障害というのは, 英語でいいますとfunctional gastrointestinal disorders, FGIDと略しま すが, 上は口から下は肚門まで, 多彩な疾患が 含まれます。本日は我々が臨床で遭遇すること が多い非びらん性胃食道逆流症（NERD：nonerosive reflux disease), 機能的ディスペプシア (FD : functional dyspepsia), これは機能性胃腸 症ともいいますが, それから過敏性腸症候群 (IBS : irritable bowel syndrome) とそれに関連 した慢性機能性の便秘や下痢を, 主に取り上げ たいと思います。

本日は 3 人の先生方にお越しいただきました. 鳥居明先生は, 鳥居内科クリニック院長ですが, 慈恵医大で 25 年間の診療経験を活かして機能性
消化管障害の研究を続けておられ, 学会でこの 分野の第一人者であります。二神生爾先生は, 日本医大の消化器内科のご所属で, 大学病院の なかで主に上部消化管疾患を専門とされておら れますが, 機能性消化管疾患に関する研究に特 に力を入れておられて, 学会で非常に活躍され ておられます。水上健先生は, 国立病院機構久 里浜医療センター内視鏡部に所属され, 病院勤 務医の立場からお話しいただきますが，機能性 腸疾患の大腸内視鏡所見という, ユニークな研 究をされておられます. 皆様, この分野の専門 家ですけれども, きょうは難しい内容はなるべ く避けて, 症例経験も含めて, 実地医家の先生 方に役立つプラクティカルな内容にしたいと思っ ております。是非，教科書には書いていないよ うな興味深いお話をいただければと思います。

ではまず初めに，どのような場合に機能性の 消化管障害を疑うか. 疑ったらどのように診断 を進めるかについてお伺いしたいと思います. 患者さんは, 自分から機能性の消化管障害とは 言ってこられないわけですから，どのようにし

Discussion Meeting on Functional Gastrointestinal Disorders.

Soichiro Miura : National Defense Medical College, Japan.

Akira Torii : Torii Medical Clinic, Japan.

Seiji Futagami : Division of Gastroenterology, Nippon Medical School, Japan.

Takeshi Mizukami : NHO Kurihama Medical and Addiction Center, Endoscopy Center, Japan. 
て診断にたどり着くのかとか, 診断の決め手な どを教えていただきたいと思います．鳥居先生， 経験を豊富にお持ちだと思いますけれども，そ ういう点でお話を伺えればと思います。

鳥居 いまご紹介がありましたように，私は 25 年間, 大学で研究生活をしておりまして, そ の後, 今は開業医として, 第一線の臨床の場で 働かせていただいております.このFGIDという 病気は, 最初から大学病院や専門病院を受診す るわけではなく, 最初は実地医家のところを受 診するのが特徵であります．自分から「機能性 の胃腸障害ではないか」という人もいますけれ ども，多くはそうではないわけです．まれには いくつかの病院を回ってきて, さらにネット等 で詳しく調べて,「自分は機能性の病気かもしれ ない」と訴える方がいるのも確かです。ただ， 多くの方はそうではなくて,「どうも胃腸の調子 が悪い」といって実地医家のところを訪れるわ けです。

どのような時にこの「機能性消化管障害」と いう病気を疑うかという問題ですが, IBD(inflammatory bowel disease: 炎症性腸疾患), FD, NERDともに機能性の消化管の病気の特徵として は，ひとつは慢性的な消化器症状があるという ことだと思います。これは，丁寧に問診を行い， 詳しく現病歴, 既往歴を聞くことでわかるわけ です。この「慢性的な」というのは非常に曖昧 な言葉ですけれども, 症状がある程度の長い期 間続くという，ひとつは「持続性」ということ です。それから，症状を繰り返すという「再発 性」という点が大きな特徵だと思います。いく つかの診断基準では, 研究や薬剤治験を目的と して，持続期間をきっちり決めるということに なっています。しかし, 臨床の現場では, 期間 としてはだいたい 1 カ月ぐらいを目安にしてい ます．胃腸の具合が悪くなったときに，だいた い 1 カ月以上調子が悪かったら，一般にはいろ いろ心配になり病院に行くのかなと思っており
ます．国際的な診断基準であるRome IIIでは，6 カ月以上前から症状があり, 最近 3 力月はいく つかの症状を満たしている場合に診断に至るわ けです。しかし，一般には，特に日本において は，それよりかなり前に，心配となり病院を訪 れるのではないかと考えております。持続期間 が短くても，機能性の病気を考える必要がある ということです。また再発ということですけれ ども, これもRome IIIの診断基準では, 1 カ月に 3 日以上にわたって症状が繰り返し起こる場合診 断に至るわけです．臨床の現場では 1 カ月の間 に 3 回以上でなくても, 症状が繰り返して起こ る場合には，機能性消化管障害を疑う必要があ ると考えられます。

機能性消化管障害を診察する上でもうひとつ 大切なことは, 器質的疾患を除外するというこ とです。それには問診を丁寧に行い，身体所見 をきっちり取るということが必要です。慢性的 な消化器症状があり, その症状の原因となる器 質的疾患を除外するということが, FGIDを診断 する際には大きな課題になると思います。これ は, 問診, 身体所見をとる際に, いわゆるアラー ムサインとかレッドフラッグといわれる器質的 疾患を疑う症状, 病歴, 身体所見に注意を払い, もしそれらがあれば，必ず器質的疾患を除外す るために，いろいろな臨床検査をするというこ とです. Rome IIIの診断基準で症状の持続期間を 3 カ月以上と長めにしているのは, 症状の持続期 間が長ければ長いほど癌などの器質的疾患は除 外できるということにつながるわけです。しか し, 実地臨床では症状が 1 カ月以上続けば不安 となり受診することが多いわけですので，その 場合もFGIDとして拾い上げる必要があるわけで す. 持続期間が短くても機能性の消化管障害と 診断する場合には, よりきっちりと器質的疾患 を除外しなければならないと考えております。

器質的疾患の除外にどのような検査をするか は問題になるところです。器質的疾患を除外す 


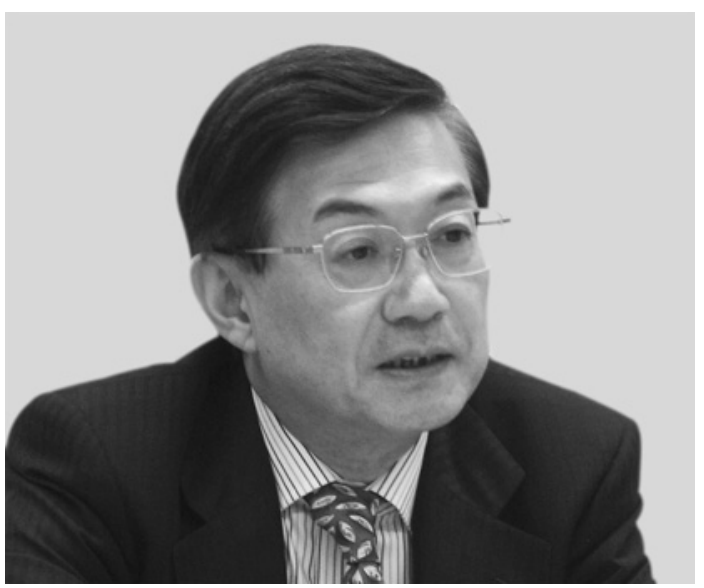

三浦総一郎氏

る際，全員に内視鏡検査ができれば一番いいわ けです，上部消化管症状の場合には比較的簡便 に検査ができますので, 全員に必ず内視鏡をやっ ているのが現状です.下部消化管症状の場合は, 大腸鏡を全員にやるかというとなかなか難しい 面があります。そこで，まずは問診，身体所見 の診察を丁寧に行い, それから一般臨床検査を 行います. 血液検査, 尿検査や便潜血反応検査, 便培養検査などを行います。そこで，たとえば 貧血があるとか, 炎症所見があるとかした場合 には，さらに詳しい検査を勧めます，便潜血反 応が陽性であれば, 炎症性腸疾患, 腫瘍性病変 も疑い大腸鏡を必ず施行しております。それか ら, 腹部単純X線検査も多くの情報が得られます. 特にIBSに関しては必ず, 腹部X線検査を行って います。それによって大腸ガスの貯留の状態が 把握できます。また小腸ガスの貯留があれば, 器質的疾患を疑うということです。それから， 腹部に腫瘤とかを触れる場合には, 必ずエコー 検査をやるということです．基本的な臨床検査 を組み合わせることが，器質的疾患を除外する 際に有効であり，実地医家でもできるところで はないかと思っております。

それから,FDの診断に関してはピロリ菌の問
題があげられます，日本においては，ピロリ菌 の感染率が高く, また胃がんの頻度も高く, 保 険上の問題もあり，ピロリ菌の検査を内視鏡を せずに最初から施行するというのは難しいと思 います.アメリカのFDに対するガイドラインで すと，ピロリ菌をまず調べて，陽性であったら 除菌をして症状の経過をみるという, Test-andtreat strategyという方法が提唱されています. しかし，日本ではピロリ菌の検査より，まずそ の前に内視鏡を行うというのが現状ではないか と思います。

NERDに関しては, 胸焼けだけでなく胸痛, 胸 部不快感として症状を訴えられる場合が多くみ られます.NERDの診断には内視鏡検査を行うわ けですが, 周辺臓器の病気を否定することも重 要であり, 胸部X線検査, 心電図検査も必要と思 われます。

三浦 ありがとうございました. FGIDの診断 について要点をお話しいただきましたけれども, 二神先生は主に上部消化管疾患を診ていらっしゃ いますが, FGIDの診断を進めていく上で, ポイ ントとなるところをお願いします.

二神私は, 大学病院で外来を診ておりまし て，お二人の先生が言われたように，この機能 性消化管障害の方は, ご自身では, 何か病気が あるのではないかということで外来にこられる 方が多いと感じておりまして, その際に診療が イドラインを参考にするわけですが, 昨年度か ら日本消化器病学会で, 機能性ディスペプシア, それからIBS (irritable bowel syndrome) もそう ですけれども, ガイドラインの委員会が立ち上 がっておりまして，現在，作成中であります. 日本のガイドラインは, 兵庫医大の三輪洋人教 授がFD (functional dyspepsia) のガイドライン 作成委員長を, IBSは東北大学の福土教授がガイ ドライン作成委員長をなさっておられ, 日本人 独自のガイドラインというのは, これから出て くるということになっております. 
鳥居先生が言われましたように，現在，私ど もとしてはRome III診断基準を念頭におきまし て，こうした患者さんが機能性の疾患であるか どうかということを考えていくわけですが，大 前提にあるのはやはり器質的疾患がないという ことになります。それぞれの先生にもいろいろ あると思いますが，私の場合は上部の消化管の 内視鏡検査と, それから腹部超音波, それから 便潜血検査の 3 つをセットにしまして，まず患 者さんにそういった検査を受けていただき，潰 瘍, 癌, 胆石, 胆囊炎とか, そういった病気が ないかどうかを，まずは帱見させていただくと いうことになっております。

一応そういった検査をしまして，患者さんご 本人に癌とか他のご病気がないということをお 話をさせていただき，次のステップに進むとい うことになります．私が外来で非常に注意して おりますことは, 患者さんの訴えておられる症 状が，主症状がどこにあるかということで，私 の場合，上部消化管が専門ですので，いわゆる 上腹部を中心としたFDの症状がメインなのか, あるいは患者さんが訴えられている症状が胸や け，胃食道逆流症状をわりとメインに訴えられ ているのかをみます．主症状が胸やけ症状とい うことになりますと, NERD (non-erosive reflux disease）というような話になってくると思いま す．随伴症状として，いまRome IIIでは，下部消 化管の症状があってもいいわけですが, 便通異 常が主体になりますと, 今度はIBSの下部の方の 機能性消化管障害ということになってくるので はないかなと考えております.

大学の場合は, そこから具体的にNERD, FD に至るまでは，いろいろ専門的な検査が可能な わけです．たとえば患者さんの訴えている症状 がFDに非常に近い, 上腹部の愁訴を主体とした ものであるということになりますと, うちの場 合はその段階で全員, 胃排出能をやっておりま す. 機能検査として, ${ }^{13} \mathrm{C}$ アテートという呼気

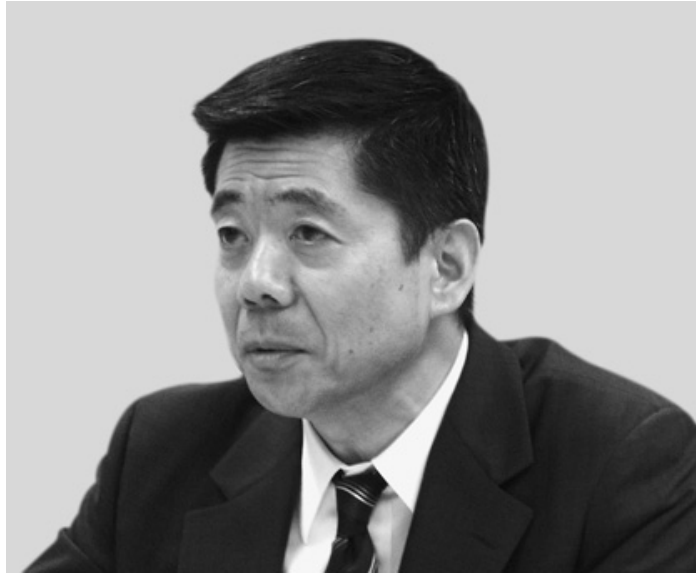

鳥居 明氏

テストをまず全員にやっていただいております.

うちでは 90 分法というのをやっておりまして, 90 分間患者さんに座って機能検査を受けていた だくわけですが，非常に簡便な方法でして，患 者さんは非常に楽でして, 基本的にはラコール という栄養飲料を飲んでいただき，エアバッグ の中に呼気を吹き込むだけです。その間にアン ケートをとらせていただいております。具体的 に申し上げますと，うちでやっておりますのは GSRS (gastrointestinal symptom rating scale) と か, それからRome IIIの 4 つの症状ですね.いわ ゆる食後の膨満感, 早期飽満感と, それから食 事と関係ない心窩部痛とか心窩部灼熱感といっ た, Rome IIIのEPS (心窩部症候群 : epigastric pain syndrome) とPDS（食後愁訴症候群 : postprandial distress syndrome)に該当するよう な, 4 つの症状をスコア化したものにつけていた だいております。

こうした機能性の消化器障害の方では, サイ コジェニックなファクターがありますので，一 緒にSRQ-D (self-rating questionnaire for depression）という，これはうつ傾向を見る質問票でご ざいますけれども，そちらにチェックをいただ くのと, それからQOL (quality of life) を評価し 


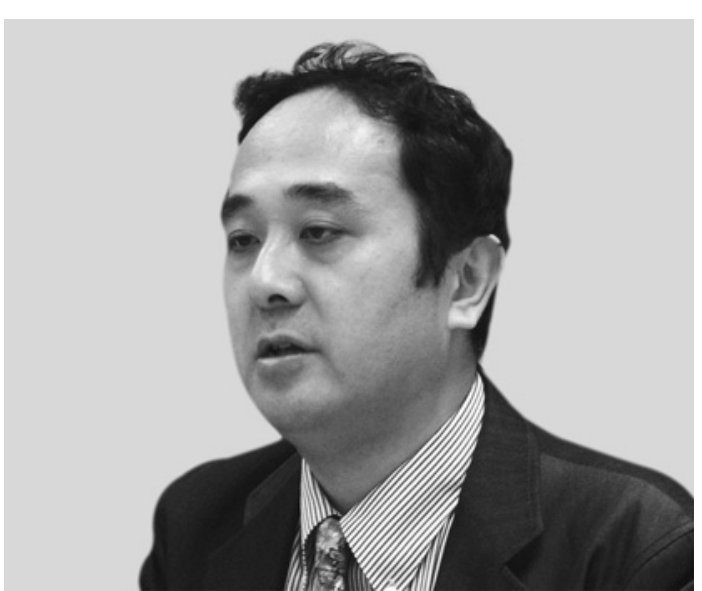

二神生爾氏

ますSF-8 と, 不安状態を反映しておりますSTAI (state-trait anxiety inventory) の検査, それか ら最近では, こういう機能性消化管障害の方に 不眠が多いということがございますので, 睡眠 の関係からピッツバーグの質問票がありますが, そちらのアンケートもとらせていただいており ます.

こうしたアンケートから，実のところ私ども は，たとえばSRQ-Dで非常にスコアが高い方が 中に抢られまして, 16 点以上あるとうつ傾向が かなり強いということになりますが，そうなり ますと, 消化器内科でそのまま診断を進めてい くことももちろんありますが, 心療内科に早め にアプローチすることも考慮に入れながら，診 断を進めていくということになります.

三浦 そうすると, 胃カメラ, エコー, 便潜 血をセットでやるというのは, どのタイミング でおこなうのでしょうか.

二神 だいたいうちに来られる患者さんは, 1 カ月ぐらい前から症状がありまして, 外来でた ぶん 1 カ月ぐらいかけまして, 来院されたとき に積極的に内視鏡とエコーをやっていただきま す.

三浦 その間に質問をして, いろいろと必要
な情報を得るということですか.

二神そうですね.

三浦 鳥居先生, 先ほどピロリ菌はtest-andtreatとおっしゃいましたけれども，ピロリ菌の 検査はどういう方にやっていらっしゃるんです か.

鳥居 当院の場合には, 一般の保険診療でやっ ているものですから, 上部消化器症状のある方 に内視鏡検查を行い，基本的には内視鏡検查を 行うときに，迅速ウレアーゼ試験で調べるとい う形にしております．胃潰瘍，十二指腸潰瘍あ るいは㓔痕病変があった場合は保険診療でピロ リ菌の検査を行います．潰瘍や瘷痕が認められ なくても，著しい胃炎病変があった場合とか, 強い症状があった場合, あるいは胃癌の家族歴 がある場合, 御本人が希望した場合には, 自費 診療でピロリ菌の有無を調べるようにしており ます．また内視鏡検査を他の施設で行っている 場合には，尿素呼気試験をお勧めしています. 潰瘍病変があれば保険診療で, なければ自費診 療でピロリ菌の検查を行っています.

三浦 二神先生のところは, いかがですか.

二神 ピロリ菌に関しては, 一応いらしたと きに採血でチェックをしておりまして, 最近は ガンの点からも除菌を希望される方が抢られま すので, そのへんはご本人と話し合って, 場合 によっては自費ということでやっています.

三浦 二神先生のところは大学病院ですので しっかり検査をされていますが, 一般では胃排 出能は調べませんし, 精神心理学的な検査もな かなか難しいと思いますが，鳥居先生のところ では，質問用紙などを使っていらっしゃいます か.

鳥居 大学の外来では, NERD, FD, IBSとも, 質問用紙を使用しておりました。症状スコア, SF-36, SF-8 によるQOLスコア, CMI (Cornel Medical Index)などを組み合わせておりました. 今はIBSの診療の際に, 症状日誌とSF-8 のQOL 
スコアを使っています. FD, NERDに関しては, 今は使っておりません. NERDの場合は, 胸焼け という症状でなく, 前胸部の不快感とか, 咽頭 部の違和感を訴えて来る方が非常に多くみられ ますが, その時点でNERDを強く疑うかどうかと いうのは, 今は感覚的, 経験的判断で診断を進 めているのが現状です. FGIDの診断においては, 質問用紙により症状をスコア化する，QOLを評 価する，背景の心理を評価するということは， 客観的な評価ができますので，きわめて有用で はないかと思っております。

三浦では,下部消化管疾患の診断に関して, 水上先生いかがですか.

水上 私のところは, IBS ・便秘外来と名乗っ てしまっているので, IBSの方が自分で名乗って 来てしまうことがほとんどですが, IBSなど機能 性消化管疾患の患者さんは長い歴史を持ってい ることが多くて，これは一般にも当てはまるこ とですが，短時間で効率よく愁訴をピックアッ プすることが重要になります。そこで長い病歴 をコンパクトにまとめて評価できるアンケート があったほうが良いと思いまして, 出雲スケー ルも良いと思うのですが，私の外来の患者さん は本当にIBSに限られていますので,これまでの 生活歴とか, 症状の変遷とか, ストレスとの関 連とか, 特にIBSの病態にかかわるものをターゲッ トにした質問用紙を使っております。

三浦 ご自分で作られているのですか.

水上 IBSの患者さんは愁訴が多岐にわたるこ ともあり患者さん自身も経過を的確に説明する のが難しいため, 患者さんが言いたいこと，こ ちらが知りたい事を効率よくピックアップでき る質問用紙を作って使用しています．他の医療 施設を何力所も回ってきている方が多いので大 腸鏡を施行することも多いです．私が今やって いるのは無麻酔大腸鏡で腸管運動と腸管形態を 評価するということですが, 大腸鏡直後にCT コロノグラフィーを撮ることで腸管形態を確認

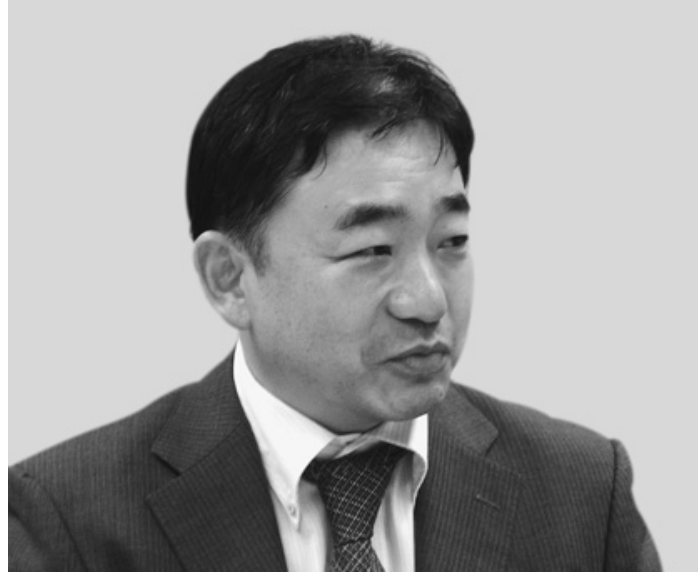

水上 健氏

しています．大腸検查で観察された腸管運動と 腸管形態を質問用紙に照らし合わせて総合的に 診察しております。

三浦 先生のところは, セレクトされた患者 さんが来院されるということですが，受診歴の 無い方がこられた場合どのタイミングで大腸内 視鏡をやるかというのは, 何か基準みたいなも のを決めてらっしゃいますか.

水上 アラームサインとか 50 歳以上というこ ともありますけれども, インターネット調査で は 2006 年の時点で $30 \%, 2010$ 年過ぎだと $50 \%$ の方が大腸内視鏡をされているんですね. 現在 大腸内視鏡がだいぶ普及していますので，炎症 性腸疾患やガンも含めて, 若年で症状が明らか にストレスによるものでなければ，一度考慮し てもいいのではないかなと思っています.

\section{更なる診断の進め方一検査や鑑別診断の進 め方}

三浦 最近, 炎症性腸疾患も多いので, 長く 下㽷が続いたような場合はIBDを疑って, 便の潜 血反応や場合によっては小腸の検査などもやっ ていらっしゃいますか. 
水上 原則的には便潜血は絶対にやるべきだ と思いますし，それが陰性でなければ，経過を 見てはいけないと思います.

三浦 鳥居先生のところはいかがですか.

鳥居 私のクリニックでは, 大腸鏡検査を行っ ていないものですから，他の施設に依頼すると いう形になります. 多くの病院では大腸鏡が一 般的になっていますけれども，まだクリニック のレベルでは大腸鏡を行うということは難しい 面が多々あると思います。したがって大腸鏡を 行うかどうかのいちばんの決め手は, 便の潜血 反応が陽性か陰性かということです．陽性であ れば必ず大腸鏡を勧めています.それ以外にも， やはりアラームサインが重要です. 血便や黒色 便があれば当然大腸鏡を钦めますが, 夜間に症 状がある場合とか, 体重減少や発熱がある場合 にも器質的疾患が疑われますので大腸鏡を勧め ています.

先ほどNERDの診断で少しふれたのですが, NERDの場合は, 胸焼けなどの逆流症状でNERD を疑うということが基本になります。しかし患 者自身も胸焼けという症状がはっきりわからな いこともあり，胸部症状として訴えることも多 くみられます。いわゆる非心蔵性胸痛として NERDの症状を訴えるわけですが, ここで必ず除 外しなければならないのは, 心疾患とか胸部疾 患だと思います，労作時に症状がある場合，あ るいは痛みが左側に偏っている場合は虚血性心 疾患を考える必要があります. NERDの場合は, 痛みの部位としては多くは前胸部中央, 胸骨の 部分を指します。また訴えとしては, 胸の中央 の痛みとか胸骨の毫側の痛みという表現を用い ます.したがって, 左側に偏っていたり, 動悸 などの心臓の症状がある場合, 呼吸苦がある場 合には, 心電図と胸のX線写真を必ず撮るように しております。また身体所見では特に心音と呼 吸音は，気をつけて聞くようにしております。

それからFDの場合には, 体重減少という訴え
は, 胃癌の存在が非常に怖いですので, 黒色便 があった場合と同様に，これは確実に内視鏡を 勧めています. 若い女性で極端な体重減少があっ た場合には神経性食欲不振症との鑑別も必要と なります．NERDの診断も，FDの診断も，現在 ではクリニックレベルでも上部内視鏡検查を行っ ているところが多く, 特に経鼻内視鏡を導入し ている場合は苦痛が少ないため, 抵抗なく上部 内視鏡検查を勧めているのが現状です．

三浦 NERDとFDも, 結局上部消化管内視鏡 検査で異常が見つからなければ,だいたいFGID を疑ってゆくというょうな手順で宜しいでしょ うか.

鳥居 基本的には上部内視鏡で症状の原因と なる病変が認められなければ, FGIDと診断して 良いと思われます。あとは，周辺臓器の異常を 除外する必要があります。エコー検査で肝臓, 胆囊, 膵臓の病変, 心電図, 胸部X線検査で心臓 と肺の病変は除外する必要があるのではないか と思っています.

三浦 二神先生も，だいたいそのように考え ていらっしゃるんでしょうか.

二神 そうだと思います．うちでも鳥居先生 が言われたように，上部内視鏡を積極的にやる わけですが, NERDの場合は, インピーダンスの 24 時間pHモニタリングがありますので, PPI (プロトンポンプ阻害薬)を患者さんにまず飲ん でいただき，症状がどの程度改善されるかとい うことを考えます．最近はPPI抵抗性のNERD の方が多いものですから，その後どうするかと いう話になるんですけれども，うちでは保険を あまり考えずにやりますと, 場合によってはPPI の倍量投与ですとか, それからさらにプロカイ ネティクスを載せまして, それでもなかなか胸 やけ症状がとれない方がいるものですから，そ ういう場合は患者さんと相談してインピーダン スをやるということになります.

24 時間のインピーダンス検査ということにな 
りますと，先ほど鳥居先生が言われたような， いわゆる実際の逆流ですね，胃食道の実際の逆 流が起こっていることと，この症状の発現が一 致するかどうかが大事になってくるわけですけ れども，一致しないということになると，いわ ゆる機能性の胸やけといいますか, functional heartburnということになります.そうすると訴 えられていることが逆流自体と少し乘離してい るということになりますので，そういう場合は 心療内科的なアプローチも考えていきます。も しインピーダンスで, acidにしてもnon-acidにし ても，逆流とその症状が一致していることを確 認して, 以降, PPIをどう使っていくかというこ とを, 患者さんと相談していく，そういう感じ になっています。

三浦 鳥居先生のところは, PPIテストはやっ ておられますか.

鳥居 NERDを強く疑い, 治療としてPPIを処 方して，その効果で病態を判断する，いわゆる 「治療的診断」ということが, 日常診療でも結果 的にはよく行われています.PPIの効き具合で病 態を判断するということは非常に大切な問題を 含んでいると思われます.最近, エソメプラゾー ルが本邦でも使用できるようになり，酸分泌抑 制効果はきわめて強く, 本来ですと症状が非常 に良くなるはずなわけです，ところが私のクリ ニックで投与したところ，何人かはあまり効か なかったことがあったのです，その原因が何か ということを考えていたのですけれども，それ を解決するヒントが最近の『Neurogastroenterology』に出ていました. PPIが効く人と効かない 人がおり，その原因を分析した論文です．効か ない人でも,さらに用量を多くすれば効く群と 用量を多くしても全く反応しない群があるとい うことです.一般的に, NERDというのは粘膜欠 損を有する逆流性食道炎に比べて, PPIが効きに くいといわれています。ささらに, pHモニタリン グやインピーダンスを調べて, 実際には酸逆流 がない方，逆流と症状が一致しない方は，functional heartburnの可能性が高く, PPIに反応が悪 いと考えられます。我が国においては保険制度 上，新らしく発売となった薬は，発売 1 年間は 長期処方が認められず, 2 週間ごとの処方となり ます.オメプラゾールの光学異性体であり, 強 力な胃酸分泌抑制効果をもつエソメプラゾール も，発売後 1 年間は 2 週間ずつしか投与をする ことができませんでした．したがって 2 週間ご とに通院することができる人にしか投与してい ないわけです．そこで 2 週間ごとに受診すると いうことは，かなり精神的な問題も抱えた人と か, わりと病気を悩んでいる人が多いというこ とになります。発売当初エソメプラゾールを投 与している人達の群というのは, 少しバイアス がかかっているのではないかということです. 酸逆流の要素だけでなく, 精神的な要素, 知覚 過敏の要素がある人たちが入ると,やはりPPI が効きにくいということが出るのではないかと 思います。

三浦 最近NERDとGERDというのは別の病気 であって, NERDはむしろ知覚過敏がメインの病 態であるという説もあるようですが, 二神先生, どうお考えになりますか.

二神 実際, 私もそういう側面もあると考え ます.ですので, NERDは実際の逆流症状があれ ば,一致してようが一致していまいがNERDにな るんですが，そのNERDのなかでも functional heartburnを除いた部分というのは, 先生がおっ しゃるように，過敏性が非常に大きなウエイト を占めているのではないかと思います．

三浦 あと, NERDとFDというのはあまり分 けられない部分もあって, 症状がオーバーラッ プするという方が多いと聞いていますけれども， ご経験ではいかがですか.

二神私のところも，実は数年前に, Rome IIの基準ですが, オーバーラップの患者さんの評 価をしたことがございまして, 確かにFD単独群 
よりは, FD+GERDそれからFD＋IBSとか, あ るいは3つオーバーラップしている患者さんの 割合を分けてみますと，圧倒的にオーバーラッ プしている方が多いんですね. ですから，主症 状がFDであって随伴症状が胸やけの方というの は，かなりおられるのではないかと考えていま す.

三浦 では下部のFGIDに戻りまして, IBS を疑うときに質問票は，鳥居先生のはどういっ たものをお使いになっていますか. GSRS (Gastrointestinal Symptom Rating Scale) かRome III か.

鳥居 クリニックで質問票を使う場合には， より実戦的で簡便なものが良いと思われ, GSRS と出雲スケールを使わせてもらっています.

三浦 出雲スケールは比較的最近, 島根医大 の木下 (芳一) 先生らが考案されたもので, 割 合と実用的で良いと思いますけれども, 水上先 生もお使いになっていると言われましたね.

水上 ええ.FDとか他の疾患とのオーバーラッ プも評価できますし，時間もあまりかからず難 しくないという点で良いと思います.

三浦 あと, 症状が上腹部なのか, それとも 下部の腸管から出るような痛みなのかというの は，患者さん自身が本当に区別できるのかなと 思うのですが，その点いかがですか.

水上 IBSでも, 腹満感や緊満感を胃の症状と とらえている人がおります。大腸鏡をやって大 腸を膨らませたり伸ばしたりすると,「これまで お腹が張っていると思っていたのは胃ではなく て大腸だったんですね」なんていうこともある ので, そこは今後，分けて評価できるようにな るといいなと思っています.

三浦 FDとIBSというのは, 日本人は胃下垂 も多いし，なかなか区別が難しいのではないか と思っているのですが, どうですか, 鳥居先生.

鳥居 ある臨床研究で, $\mathrm{H}_{2}$ ブロッカーでFD を治すときにQOLの調査をしたのですけれども，
FDに便秘が合併している場合には, 便秘が治る か治らないかで，QOLの改善に差があるという ことが出ました。一方，FDとIBSが合併すると QOLの低下が非常に強くなるということも，欧 米の文献に出ています。「消化管は 1 本の管」と よく言われますけれども, やはり個々の臓器は 密接に関連していて, 特にQOLで見ると, 一つ 一つの個別の症状というょりは, 全般的な感覚 として捉えられるため, FDとIBSが合併すると， QOLがすごく落ちるのではないかと思われます.

三浦 1 本の管という考え方は, 私も非常に大 事な概念だと思います．また, IBSという言葉が 非常に流行っていますけれども, 慢性機能性の 下痢や便秘などと，なかなか区別がつきにくい と思うのですが，そのあたりはいかがですか.

水上 コマーシャルでIBSが広く認知されるよ うになったのはとても良いことなのですが, IBS という言葉が独り歩きして，下痢をしてさえい れば「自分はIBSです」と言って来るようなこと も増えました，そういうことからすると，症状 に気をつけないと, 慢性下痢とか他の下痢を伴 う疾患が間違えてIBSに入ってしまっている可能 性もあるのではないかと思います。そういう点 では, Rome IIIなど診断基準できちんと仕切る必 要があるのではないかなと思います.

三浦 そのときに，腹痛の有る無しというの がひとつポイントになるという話があると思い ますが, 鳥居先生, その辺はいかがでしょうか.

鳥居 日本では, IBSというと下㢉と便秘, 特 に下痢で困っている人というイメージがありま す.しかし, IBSの本体というのは腹痛と腹部不 快感, これがRome IIIの診断基準でもメインにな ります.これがなければ逆にIBSとは言えないと いうことで, 機能性下痢あるいは機能性便秘と して区別されています. QOLの低下には, 便通 異常もさることながら, そのときの切迫感とか 腹痛, 腹部不快感が強く影響していると思いま す，逆に腹痛や腹部不快感がない場合には，か 
なり便秘がひどくても元気に働いている方がた くさんいらっしゃいます。便秘の女性では 7 日 間ぐらい出なくても平気な方もいるので, その ときに苦痛を伴うかどうかというのは, QOL を考える上で非常に大きい要素になるのではな いかと思っております。

三浦 あと, FGID全般的に, 夜間は症状がな いとか, 体重減少がないということが言われま すが，体重減少はある人も結構いるような気が するのですが，いかがですか，心配して食事を 控えてしまう人がいるのではないですか.

水上 ただ, IBSの重症の方で, 排便が怖くて 本当に䀧食障害になってしまう方は確かにいらっ しゃいます.

鳥居 IBSの場合には夜間に症状がないという のは特徵と思われます. NERDやFDでは結構夜 間にも症状が出る方はいらっしゃいます. 特に NERDでは明け方に症状が出ることもあります. 体重減少に関しては，基本的には機能性疾患で は体重は減少しません。しかし, 若い女性で神 経性食欲不振症の傾向がある場合, あるいは症 状の出現を恐れて，意図的に食事を制限してい る場合には体重減少が見られます。以前に胃潰 瘍, 十二指腸潰瘍の研究をしていた時, 臨床症 状で胃癌との鑑別ができないかという検討をし た事があります。そのときの結果では, 痛みな どの症状には有意差はなく, 体重減少にだけ有 意差がでました．胃潰瘍や十二指腸潰瘍でも， もっと体重が減るかと思ったのですが，あまり 減少せず，胃癌の場合には顕著な体重減少がみ られたわけです，当然昔の研究ですから，進行 癌も多く含まれています。しかし，いずれにし ても体重減少があるということは, 特に高齢者 においては悪性疾患を疑う大きな要素になると 思われます。
有効な治療を行うにあたっての診療のポイ ント

三浦 次に, FGIDと診断をつけたら, どのよ うに治療を進めるかという点に関して, どの時 点で実地医家から専門医に相談したらいいかと いうことも含め教えていただきたいと思います. また, 患者さんに対して, 生活指導とか食事療 法とかを含めて, どのように説明していくかと いうお話もお聞かせいただきたいと思います．

鳥居 FGIDの発症には, 生活習慣が密接に関 連している，ある意味では生活習慣病のひとつ ではないかと思われるときがあります。それぞ れに多少違いがありますが, 私はFGIDの治療に おいては $5 つ の$ 柱があると思っています。まず 第一は病態の説明です。患者自身がその病気の 病態を理解することが大切で，まず病態の説明 を，検査結果を交えて丁寧に行います．

2 番目は, 生活指導です.やはり生活習慣とい うものが大きく影響します。欧米では生活の中 に認知行動療法を取り入れ, FGIDの治療に大き な効果をあげています. 私は特に, 100 点を目指 さないで 75 点を目指そうという「75 点主義」を 勧めています。これは，がんばり過ぎるといろ いろ病気が出てくるということをわかりやすく したものです．それから，行動では毎日歩くこ とを锥めています. 11 日 20 分から 30 分ぐらい 自分の健康のために歩く時間を作りましょう. まず騙されたと思ってやってみましょう」と指 導しています。一定時間を歩くことにより，腸 の動きも調節され, 感覚の過敏も改善されます. 消化管の運動の異常, 感覚の異常が改善され, 効果がでるわけです.

3 番目は食事療法になります. 食事に関しては, 特に上部の場合には胃排出に時間のかかる脂も のを控えたり，夜の遅い時間の食事を控えても らっています. IBSの場合には, 下痢型と便秘型 
でそれぞれ指導が異なります。下痢型では油も のを控え消化の良いものを摂るように勧めます. 便秘型では水分を多く取り, 繊維質の多い食物 を勧めます。

4 番目は, 薬物療法になります. それぞれの疾 患により薬剤の選択は異なりますが, 受診後は 薬剤を早めに出してあげるということを行って います．当然適切な薬片を投与することは症状 の改善につながります．それだけでなく, FGID はプラセボ効果が高い疾患であり，早期に薬を 貪うことにより安心感が生まれ，早期に患者と 医師の信頼関係が構築されると考えられます.

それから, 5 番目は心理的な療法です. FGID の治療においてはこの心理療法がきわめて重要 といえます.アメリカの専門施設ですとセンター 化されており, 消化器内科の中に心理学の先生 がいて, 心理テストによる分析, 心理療法を行っ ている施設もあります. 日本では, 心理学の先 生との協力は難しいですが, 診療内科, 精神神 経科との先生との協力は比較的容易と思われま す. 内科の外来で専門的な心理療法を取り入れ るのはかなり困難といえます。私の場合は, 特 に初診時に時間をかけて，いろいろな訴えを聞 いてあげる, 簡易精神療法を行っています。傾 聴, 受容, 保証という簡易精神療法を行ってい るわけです。良く訴えを聞き，「大丈夫ですよ」 というような安心感を与えることが, 日常診療 でできる大切なことではないかと思っています.

三浦 病態の理解のところは, どのくらいの 説明をされますか. たとえば脳腸相関とか, そ んな話もされるのですか.

鳥居 FGIDは, NERDも, FDも, IBSも消化 管の運動の異常と感覚の異常から症状が発現し ている. 運動の異常が, 逆流とかもたれ, 下痢・ 便秘の原因となり, 感覚の異常が腹痛, 腹部不 快感の原因になっていることをお話しします. それから, 脳と消化管の関係を脳胃相関, 脳腸 相関という言葉で説明します。脳と消化管は密
接に関連しており，胃であれば「胃は心の鏡」と いう言葉を用いて，ストレスと消化管の密接な 関係を示します。ただ運動機能が落ちているだ けではなくて，感覚も非常に敏感になっている ということを示します，ストレスが消化管運動 や感覚の敏感さに影響を及ぼしているというこ とを，わかりやすく説明するように心がけてい ます.

三浦 歩行指導は, 実際に効果があるのです か.

鳥居 歩くことは, 行動療法の一つであり， 効果はあると思われます。いろいろなことを指 導してもなかなかわかってもらえないことがあ ります。それから，難しいことを言ってもでき ないということもあるのです，たとえば犬も， 朝夕，散歩に連れていけばストレスがなくなっ て鳴き止むし，お通じも出るわけです，誰にで も歩くということはできますし，雨の日も風の 日もできます。お金もかからない, 生活習慣病 もよくなります。最初は 10 分でも 15 分でも良 いと思われます. IBSの患者さんは, 外に出ると トイレに行きたくなるから歩きに行かれないと いう人もいます。しかし, 家の周りだけだった ら, 1 周ぐらいはできるのではないかということ から，お勧めしています。

三浦 二神先生は, いかがですか.

二神私も，いまお話に出ましたようなアプ ローチになっておりまして，まず検査が終了し て，FD，NERDであるということがわかりまし たら，「癌とか潰瘍がないので，まず大丈夫です よ」.これは悪性の病気ではないですからという 話をさせていただきます.また，ドクターショッ ピングする方やなかなか原因がわからずに, 症 状が取れずに心配なさって来られる患者さんが おられますので，そういう方には，機能性の検 查などである程度結果が出ましたら, それを伝 えてあげます。そうするとその後, 症状がよく なる，ならないは別にしまして，おそらくこう 
いうことが原因で，少し胃もたれや胸やけが出 ているんだということがわかりますので，それ なりに患者さんが納得していただける場合があ れば，なるべくそういった原因となるような要 因を話してあげます。ご理解いただくというこ とから始めまして，あとは鳥居先生が言われた ような, 薬物療法に入る前に生活指導としては, よく言われます脂肪分を少し控えていただくと か, あるいは喫煙などがFDの患者さんの症状を 悪くするという報告もありますので, 喫煙はで きれば控えていただくというような話をさせて いただきます。

実際の薬剤に関しましては, 患者さんの訴え によるんですが，たとえば心窩部痛が強いよう な, いわゆるEPS (窩部痛症候群) の症状が非常 に強いような方は, 場合によってはいきなりPPI から始めることもありますし，あるいは酸分泌 抑制剤から $\mathrm{H}_{2}$ ブロッカーを含めまして入ってい くということが, 私の場合は多いです. 排出機 能をやりまして, 胃の動きが悪い方の場合には, 比較的早期からうちの場合はプロカイネティク ス, 消化管運動賦活薬を積極的に使っていくこ とが多いです。ただ，酸も非常に重要なファク ターだと思いますので，酸分泌を抑えながら消 化管運動の改善薬を使っていきますが, 場合に よっては漢方を使うこともあります。

三浦 機能的検査の結果を伝えると，やはり 効果はありますか.

二神 実際に，たとえば排出能検査などは数 字で出ますので, 完全にこれは正常か異常かと いうことで，その数值をお見せしますとかなり 納得されます。いま胃の排出機能というのは, 症状と特に特異性はございませんで, 改善した からある症状がよくなるというわけではないの ですが, ただFDやNERDの一部に関しても, 病 態の一部を形成しているものですから,「そういっ たところの一部は少し障害されているようです ね」という話をさせていただくと, 納得されま
す.

三浦 いま二神先生のほうから, PPIなど酸分 泌抑制剂とかプロカイネティクス, あとは漢方 のお話などが出ましたけれども，鳥居先生も， そういう薬荗を組み合わせてお使いになってお られますか.

鳥居 基本的には，やはり同じような方法で 薬剂を組み合わせて使っております.NERDに関 しては, 特にPPIが有効といえます. しかし保険 上は, 粘膜欠損がない場合は, PPIを半分量しか 使えない.すなわちNERDの場合は, PPIは全量 使えず，半分量でしか使えないのですが，実際 的にはPPIを全量使っているのが現状です.それ とプロカイネティクスを加えて処方しておりま す.さらになかなか治りにくい人には六君子湯 を加えたりします。

FDに関しては, 症状が強い場合には, EPS でもPDS（食後愁訴症候群）でも，両方とも $\mathrm{H}_{2}$ ブロッカーの半量を使用しています.それから， 防御因子製剂を使用することも多いと思われま す. 防御因子製剤のFDに対する効果を示したエ ビデンスは出ておりません。 しかし, 患者さん は 1 日 1 回飲む薬よりも, 1 日 3 回飲む薬という のが, どうも胃薬としては効いているような気 持ちを持つようです．安心感を与えるという意 味でも，防御因子製剂を処方しております．FD に対して防御因子製剤を処方すると，臨床的に は確かに症状の改善を認めております.それと， あとはFDに対しても当然プロカイネティクスを 併用しております。ささらにそれでもよくならな い場合には，六君子湯などの漢方を処方すると いうことを行ってます.

先ほど診断のところで出てきたいろいろな検 査は, 患者さんに「潰瘍や癌などの心配な病気 はないですよ」ということを保証してあげると いうことで，診断だけでなく治療の上でも症状 を取るうえで大きな効果になると思います。内 視鏡を行い，潰瘍や癌などの病気が認められな 
くても, 胃痛, 胃もたれなどの症状が出るとい うことを示すことが, FGIDの病態の理解につな がり, 治療効果が期待できます。病態を詳しく 説明する面では, NERDにおいてインピーダンス 法で胃酸の逆流状態を示すことは, 治療上も非 常に有効ではないかと思っております.

三浦ところでピロリ菌抗体陽性の場合は, 積極的に除菌をされておりますか. 保険の問題 があるのですけれども.

鳥居 ピロリ菌抗体陽性の場合は内視鏡を行 い, 病変を観察し, さらにピロリ菌の存在を迅 速ウレアーゼ検査, 病理検査, 尿素呼気試験な どで確認してから除菌療法を行っています。現 在胃癌ハイリスク検診として, ペプシノーゲン 法とピロリ菌抗体を組み合わせた $\mathrm{ABC}$ 法が行わ れています。検診においても，ペプシノーゲン 法陽性あるいはピロリ菌抗体陽性の場合は，ま ず内視鏡を行い, ピロリ菌の存在を確認し, 除 菌を権める方法を取っております.FDの場合は, 症状があるわけですから，必ず内視鏡を行い， 生検をして迅速ウレアーゼ試験を見て,陽性だっ たらその時点で患者さんに説明をして除菌療法 を行います。ピロリ菌の検査, 除菌療法は, 潰 瘍病変を認めれば保険診療で, 認められなけれ ば自費診療で行います。ピロリ菌が症状の原因 となっている可能性もあるので，まず除菌をし ましょうというょうに説明しています，以前は ピロリ菌によるFDという考え方がありましたけ れども, 今はFDとピロリ菌感染症とは分けて考 えるという方向になっています. 胃の症状があ り, 内視鏡で症状の原因となる病変が認められ ず，ピロリ菌陽性の場合は，まずはピロリ菌を やっつけてみるというのがひとつの方法だと思 います，病態を十分に説明し，患者さんが除菌 療法を望む場合には, 潰瘍病変がなくても自費 診療でピロリ菌除菌を先にするようにお勧めし ています。

三浦 二神先生もだいたいそのような方針で
すか.

二神そうですね. FDの場合, 除菌の治療効 果は, 先生方ご存じのとおりあまり高くはない ものですから，どうするかというのは難しい問 題です．ガイドラインでも技そらく，ピロリ菌 の感染症と機能性ディスペプシアを分けて考え る方向に向かっておりますので, そのへんは分 けなければいけないのですが, 私も実際のとこ ろは, ガンの予防というお話を患者さんにいた しまして, 患者さんも最近はよくご存じですの で，場合によっては除菌をするというようなス タンスでおります。

三浦 ありがとうございました．次に下部の ほうの話に移りたいと思いますが, 水上先生は, IBSとか慢性の機能性便通異常の方には, どう説 明して, どのような治療をどの夕イミングで行っ ておられますか.

水上 まずは, ご本人の症状を認めてあげる ということが重要ではないかと思います．患者 さんは本当に苦しんで来ているわけなので, そ れをきちんと受け止めてあげるということ，あ とそういう状態とうまく付き合っていくという ことを最終目標に持っていくのが重要なのでは ないかなと思っています.

私は内視鏡でIBSのメカニズムが見えるという ことをやっております．そもそも大腸鏡は痛か ろうが痛くなかろうが「検査自体がかなりの心 理的ストレス」を引き起こすものですから心理 的ストレスが原因で症状を引き起こしている場 合，無麻酔大腸鏡ではブスコパンを投与しても 強い腸管運動が出てオナラがブウブウ出たり肛 門から便汁が吹き出して検查台を污します。こ の時「オナラを止めてください」と言っても患 者自身の意志ではオナラを止められません。モ ニターを見せながら検査を施行していますので 「実際に心理的ストレスでこのように腸が動くん ですよ」とストレスによって起きる腸管運動を 自分の目で確認していただきます. 
あと，心理的ストレスではなくて腸管形態異 常が原因で症状が出ている方がいます。症状は IBSですけれども,ご本人たちに聞くと症状が発 現するタイミングでは心理的ストレスを自覚し ていません．私自身がドイッで大腸鏡を 100 例 以上施行してわかったのですが，日本人はドイ ツ人など欧米人に比べると下行結腸やS状結腸な ど肛門側の腸管形態異常の頻度が非常に高いの です．症状が発現するタイミングとストレスと は全く関係がないということを扔しゃる方の ほとんどに教科書的腸管形態と異なる, 排便障 害の原因となる腸管の捻じれや捻じれ口側の拡 張が存在しています．内視鏡で炎症や癌がない ことを確認して患者さんの不安を解消し, CT コロノグラフィーでそのような排便障害の原因 となる腸管形態異常を確認してもらいます．こ

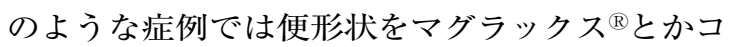
ロネル®で緩めに調整して口側腸管が拡張する腸 の捻じれ近傍のマッサージをしてあげると症状 が非常によくなります.

最近塩酸ラモセトロン (イリボー $\left.{ }^{\circledR}\right)$ というす ごくいい薬が出ました.イリボー ${ }^{\circledR}$ は腸管運動異 常というか, ストレスが病態に関与するIBSには 特効薬といっていいぐらい効きますので, 器質 的疾患を除外してイリボー『処方して効かな かったら他のことを考えればいいと思います．

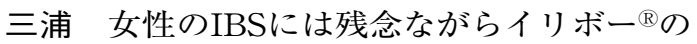
適応は認められていませんね.

水上そこがいちばん重要なところだと思い ます。もし女性にそういうような症状があった ら社会に出ていけない可能性もあるのではない かと考えています．この間，あるテレビ局のア ナウンサー室の人に聞いたらIBSの人は一人もい ないと言われました，他の部門や制作会社には 結構いるのですが. 現在でも女性は男性に比べ て就職率が低いということと，日本はまだトイ レに行くことを恥ずかしいと思う文化がありま すので下痢で生活に支障が出るような女性は仕
事に就けていない可能性があると思います．と いうことは逆にいうと通勤や会議でのプレゼン など切迫するようなストレスがありませんので,

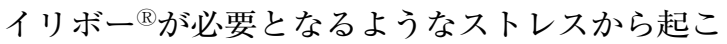
している下痢で困っている女性は少ないのでは ないかと思います。アメリカでは逆に女性から の要請で再適応になった種類の薬ですが, 日本 はまだアメリカのような社会にはなっていない

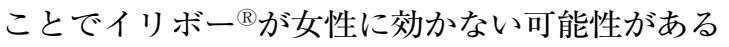
のではないかなと思います。

三浦 そういう考えもあるわけですね.あと， どういうタイミングでお薬を投与するかですが, 最初から受診された際に処方をしてしまうのか, それとも大腸鏡などをやってはっきりわかって からお出しするかというのは, どうされますか.

水上うちはえらい辺鄙なところにあるもの ですから，皆さんあちこちの病院をかかって治 らないとのことで遠くから苦労していらっしゃ います．最近の傾向として見られるのは，イリ ボー ${ }^{\circledR}$ が出てからは腸管運動異常が出る方という のはほとんどいなくなってしまったことですね. 数年前は大腸がグジュグジュ動いて,「あ, 動い てる」って見せられる人がいたんですけれども， 最近はそういう人たちが既にイリボー『飲んで しまっていて.

三浦 先生のところへたどり着かないという.

水上イリボー『を飲んだことがない方がたま に来て，処方して著効してすごく喜ぶことがあ りますが，最近本当にそういう方はクリニック などのプライマリーケアでよくなってしまって いるのではないかなと思います.

三浦 それから抗不安薬や抗うつ薬とか, さ らに精神心理療法などは, どの段階で使ったら いいでしょうか. 先生のところは自律訓練法と か, バイオフィードバックとかを施行されてい ますか.

水上 内視鏡やCTコロノグラフィーで「癌や 炎症がないこと」を確認して安心させたうえで 
腸管運動や腸管形態など「症状の原因となる腸 管の異常があること」を患者自身の目で確認さ せて症状に対する対策を考えるという認知行動 療法みたいな形で使っています。あともうひと つ重要だと思っていることは，会社とか学校に 通っている方を休ませないということです．会 社や学校でのストレスが症状の原因だった方は 休むことで改善することもありますが，腸管形 態異常で排便障害を起こしている方は運動不足 になって排便障害がさらに悪化しますし，一日 中病気に浸ってしまって精神的に不安定になり 会社を辞めたり引きこもりになる方が多くみら れます，そういう方には，「会社や学校に行くこ と自体が運動量を確保することや病気に浸らな いようにする意味で治療なんだよ」ということ で少し無理させても復帰を試みます。

三浦 先生は, 精神的なサポートも一緒にや りながらやっておられるわけですね，鳥居先生 もそうおっしゃっていましたけれども.

鳥居 いまIBSにおける腸管の運動異常の話が あったわけですけれども, 特にIBSの患者さんは 腹部の張りとオナラのことで悩んでいる方が多 いようです. IBSにおける腸管の運動異常, すな わち腸管の弛緩障害と痤攣様の収縮ということ が，腹部膨満や痛みの原因となっており，まさ にそれを大腸鏡で見られているのではないかと 思います。

精神的サポートに関しては, IBSとうまく付き 合っていくという考え方が非常に大切ではない かと思います．欧米の考え方というのは, 病気 と戦い, 病気を治すというのが主体になると思 います. IBSにおいては日本的な考え方かもしれ ませんが, 100\% 治すのは難しいので, 75\%ぐ らいでも満足し，あとは病気とうまく付き合っ ていきましょうと説明します。いくつかの病院 を回ってきている方も多くいますから，ここで も症状が $100 \%$ なくなるようなそんな特別な魔 法のような方法があるわけではないということ
を納得してもらっています。そして, IBSとうま く付き合っていく方法を打教えすることはでき るかもしれないというような対応をしています.

それから私のクリニックでは, IBSの場合には IBSセットというクリニカルパスがあり, 診断も 治療もそれに沿って行っています。これはノー スカロライナ大学のDrossman先生の消化管運動 機能センターの方法を参考にしております。機 能性消化管障害が疑われる場合には, 器質的疾 患の除外の検查, 消化管運動機能の検査, 心理 検査をセンターで行い，全部のデータを持って 外来に戻ってきて，主治医の診療を受けるとい うものです．そこまではできないのですが, 私 のクリニックでは, まず問診, 身体所見の診察 を行った後に, 腹部X線検查, 血液検査, 尿検査, 便潜血検査, 便細菌培養検查を行い, 外来に戻っ てきます。そこで病態を説明し, 生活指導, 食 事指導，簡易精神療法を行い，薬剤を処方する という方法です．まず外来で診察し，検査室で 器質的疾患の除外を行い, 外来に戻ってきて, そこでセットの薬を出していくという一連の流 れを, クリニカルパスの形で電子カルテのオー ダーに沿って行います.

薬物療法に関してですが, やはり男性の下痢 型の場合には, 塩酸ラモセトロン (イリボー $\left.{ }^{\circledR}\right)$ が特攻的に効きますので, 最初からイリボー『を 投与します。それこそPPIテストと同じょうに, イリボー ${ }^{\circledR}$ が効かなかったら，もしかしたらIBS とは違うのではないかと思うぐらいに, 特効的 に効いてくれます，女性は治験のときに，集ま る人数が少なかったということもあって, 残念 ながら有効性を示す有意なデー夕にならず，保 険適用にはならなかったわけです。しかし，女 性の下痢型IBSの方で, イリボー ${ }^{\circledR} の$ 使用を希望 される方も多く, 保険適応が得られることを期 待しております。

それ以外の場合には, 下痢型も便秘型も水分 量を調節するポリカルボフィルカルシウム（ポ 


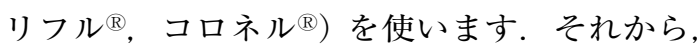
IBSの場合は大腸のガスが多いというのが大きい 特徵ですが, 腹部X線検査を行い, ガスの状態を 観察すると, IBSの患者さんは下痢をしていても ガスが多いことがわかります。これが腹部症状 の原因になっていると思われますので，ガスを なくしてあげるために, ジメチコン (ガスコン $\left.{ }^{\circledR}\right)$

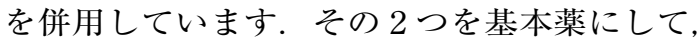
それにプラスする形で，下痢型の方は止痢剤を 使用します。フェロベリンとか整腸剤とか， ロ ペラミド (ロペミン $\left.{ }^{\circledR}\right)$ を使います。便秘の方に は，酸化マグネシウムを使用します．古くて安 い薬ですけれども, 酸化マグネシウムは量の調 節が効き，便を軟らかくするには効果的です．

さらにプラスして刺激性の下剤ピコスルファー トナトリウム (ラキソベロン $\left.{ }^{\circledR}\right)$ を使うというよ うな方法をとっております。

特に腸管の収縮が強く痛みがある人には，臭 化チキジウム (チアトン $\left.{ }^{\circledR}\right)$ などの抗コリン剤を 使用します。あとは, 症状が多彩で非常に不安 感の強い人には, トフィソパム（グランダキシ ン®) 等の安定剂的なものを使います。日本にお いてはなかなか抗うつ薬を使うことは難しいと いえます．欧米のエビデンスでは，抗うつ薬の ほうがIBS症状に対して効果があるのですが, 保 険適応外でもあり，実際に処方するには勇気が いると思われます。

三浦 私も，最初からなかなか抗うつ薬まで 簡単には出しませんが, 実地医家の先生方が抗 うつ薬などを処方されるときは, やはり精神科 や心療内科などの専門医に相談したほうがいい ですか.

鳥居 文献的にもうつに効く投与量より少な い量で効果がでていますので，うつ症状を治す のではなく, 閾值を上げてくれる効果だといわ れています。ですから，患者さんに良く説明し て, 納得していただければ, 使うことは非常に いいと思いますし，効果も期待できます。また functional abdominal painみたいに，どうしても 痛みが治まらない場合に使うというのは，ひと つの方法だと思います。しかし，抗うつ薬は， 逆にお腹が張ってしまうという副作用もあるの で，そのへんの使い方は今後，トライしていか なければいけないことだと思います。

水上 女性の場合だいぶ数は少ないですけれ ども, ストレス誘因のものに関してはイリボー ${ }^{\circledR}$ の代わりにセディールが有効だと感じています. セディール®は長く使わなければ効かないと言わ れていますが私の経験ではストレス誘因の症例 では数日以内に効果が出ますし, 効果が出始め てからは内服後 1 時間ぐらいで症状が消えるこ とが多いです.セディールは倩あまり使われてい ないようですが私にはかなり印象がいい薬です.

三浦 その他に，プロバイオティクスとか漢 方薬などは，お使いになりますか.

水上 整腸剂を足してうまく合うと症状が消 えてくる方もおります。また便秘と下痢を繰り 返してというIBS混合型が, 内視鏡やCTC (CT コロノグラフィー）で見てみると大腸鏡挿入困 難症例である腸管形態異常の方が非常に多いで す．固い便の「栓」が腸管形態異常の捻じれで 引っかかりそれが抜けると, 大腸癌やS 状結腸軸 捻転症によるイレウスでの腸管内容は泥状便や 水様便ですが，それが出てくるような感じで口 側の拡張した腸管からドバッと体重が 1 ～ $2 \mathrm{~kg}$ 減るぐらい泥状便や水椂便が出て, また詰まっ て，出てという感じになっています，そのよう な方に関しては下痢症状があってもマグラック ス ${ }^{\circledR}$ やロネル®で固い便の栓を作らないように 便を緩めにして運動療法を併用すると逆に便の 形が出てきて便性状が改善します.

\section{診療上の注意点一経験からのアドバイス}

三浦 皆さんから診断・治療に関する貴重な お話が聞けましたが，次にいままでの診療のな 
かで,こんなところは注意したほうがよいとか, 失敗例とかをお聞かせ願えませんか. 最初に, 鳥居先生から.

鳥居 IBSの場合,一応診断と治療のアルゴリ ズムが決まっています。それで，アラームサイ ンがあったら，それに対応したいろいろな検査 をするとか, 便の潜血反応が陽性だったら大腸 鏡をやるとか, ある程度のストラテジーが立て られています。しかし, 婦人科疾患がその網か ら抜けてしまうことがあります。当然, 身体所 見を取る時にお腹を触ります。腫瘤があれば気 づくわけですけれども, 下腹部を触れても, 女 性の場合, 非常に脂肪が多かったりするとわか りにくいことがあります.ご本人に「前からこ んなものですよ」と言われると，ついついそこ を通過してしまいます.私の経験したIBSのなか で何例か, 子宮筋腫が大きかったり, 卵巣腫瘍 が大きかったりして，それが腸管を圧迫してい て症状を出していたという方がいらっしゃいま した.もう少し詳しくお腹を触っていればよかっ たのかなと思いますが，他の検査では発見でき ず，婦人科疾患には注意が必要といえます。

それから, 下痢型のIBSの場合, 当然, 膵臓と か甲状腺に関しては, 血液検査を行いますから， 異常があればすぐわかります。怖いなと思った のは, 大腸癌が直腸にあるときに, 下痢症状が 出ている方がいます. 慢性的に下痢が続くため, いくつかの病院で過敏性腸症候群だと言われて いました．当院で便潜血反応を行ったところ陽 性だったため大腸鏡を施行したところ，直腸に 進行癌があったということがあります，下痢を しているからといっても, 大腸癌の存在を忘れ てはいけないということが教訓になりました.

最近の話題としてはIBSとUC (ulcerative colitis : 潰瘍性大腸炎) とかクローン病との垣根が なくなってきたことです. 以前はUCやクローン 病などの炎症性腸疾患 (IBD) とIBSは，1字違 えばまったく違う病気と思われていました。し
かし, IBSをずっと診ていると, IBDが発症する. IBDが治ってもIBSの症状が残るということがあ り, 特に最近, IBSの直腸にmicroscopic colitis (顕微鏡的大腸炎)の所見が認められるなどの問 題などが出てくると, IBSとIBDの垣根がだんだ んなくなるんじゃないかと思われてきました. このことに関連して 1 例, 怖い思いをした症例 があります. IBSだとばかり思って当院の外来で ずっと診ていましたが, 本人はどうも調子が悪 いので入院したいというので, 大学病院に入院 して，いろいろと調べてもらいました．しかし 検査では何も異常は見つかりませんでした，最 後にもう一度大腸鏡をやりましょうといって検 査をしたところ，UCの所見が認められました. 当院外来でも, 入院時も, 便潜血は陰性でした. どこかの時点でUCが発症したのか, 以前からUC だったが出血病変が途中から出現したのか, ど ちらかはわかりません. しかし, IBSを診る場合 には常にUCとかクローンの合併を考えなければ いけない.あるいはIBSでなくて, IBDかもしれ ないという可能性を考える必要があると思いま した。

それから精神的なことでの注意ですが, 我々 すぐ患者さんを安心させようと思って,「大した ことないですよ」という言葉を使うことがある と思います．当院に来た下痢型IBSの一人が, 「ここで治らなかったら自殺をしたい」という話 をしました．なぜかというと，「どこに行っても

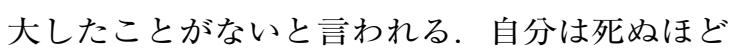
こんなに苦しんでいるのに，大したことがない と言われるのは非常に不本意だ」ということを おっしゃっていたのです.「大したことないです よ」と安心させようと思う言葉が，患者さんに とっては非常に苦痛だったというのを聞いて, 気をつけなければならない言葉だと思いました.

三浦さっきおっしゃられた, IBDとかmicroscopic colitisは, 実際のところはIBSと鑑別が難 しい場合も多いと思います.私の診ているクロー 
ン病の患者さんの中にも,ずっとIBSとして診断 されていたという方が意外に多く, 以前の内視 鏡を取り寄せて見てもやはり所見が無いという 場合もあります．見逃していたのではなくて, いつの間にかIBDへ変わった可能性もあるという ことで, 今後の研究課題かなと思います。あり がとうございました：二神先生，どうでしょう か.

二神私も，いちばん大事なところはやはり， 器質的疾患をルールアウトするところかなと思 いまして，うちでも，おそらくFDだろうという ことで，先に述べました排出能をやっているん ですけれども，いままでおそらく500 症例以上 になるんですが, そのなかでも 1,2 名の方, 確 か膵ガンの方が拈られまして，そういう意味で は，見逃さないようにするというのが，いちば ん大事かなと考えております.

もうひとつ注意点としましては, 先ほど出ま したオーバーラップですが, うちのほうでもそ うですし，あと本郷（道夫）先生とか三輪先生 のグループのお仕事でもそうですけれども, オー バーラップの, 特にFDとNERDと, それからIBS, ぜんぶ合併しているような方というのは，非常 にうつ傾向といいますか, SRQD(うつ自己評価 表) とかSTAI (状態特性不安検査) などをやり ますと,そういうサイコジェニックなファクター が非常に強い方が多いものですから．日常的な 診療でいうと, 胸やけもあるし胃も痛いし, 便 通異常もあるというような, 多彩な消化器症状 を訴えられる方は, やはりそういったサイコジェ ニックファクターを注意する必要があるかなと いうのが，印象ですけれども.

3 つ目は, 私もこれは失敗したかなという症例 がありまして，それは先ほどちょっとお話に出 たような摂食の問題ですが, 若い女性の方で, 最初, いわゆる腹部膨満感ということで通って おられて，非常に真面目な方ではあったんです が，食事がとれないのでとらないと．とらない
ほうが楽であるということでずっと通っておら れたんですけれども，だんだん瘦せてきてしま いまして, 実際のところはanorexiaであったとい う方が扔られまして.

よく調べてみますと,いわゆる anorexiaほどで なくとも, eating disordersというのがありまし て，そういうところの範疇には多少, FDとか機 能性の消化管障害がオーバーラップしてるのか なという症例がありまして，あまりにも体重が 減ってくる場合, その方などは, SMA（上腸間 膜動脈）症候群を起こしまして, 結局, 入院し ていただいたんですが，そういう方はやはり消 化器内科だけではなくて, いろいろなアプロー チが必要かなと思っています.

三浦 重症になってくると, 精神心理的な異 常というのが強く出る方が多いのでしょうね. 水上先生は, どうでしょうか.

水上 私は患者さんを診る前に, やはり嗜好 歴，アルコールやコーヒーをどのくらい飲んで いるかを聞く必要があると思います．以前， 60 代の男性が慢性下痢で治らないということで大 腸内視鏡をしたところ，盲腸のところに血液み たいなのがありまして, 慌てて上部内視鏡もやっ たら上も何もありませんでした，要するにコー ヒーを 1 日 10 杯ぐらい飲んでしまうという人で, コーヒー残渣じゃないですけど，本当に血液に 見えたのですが，検査前にこっそり飲んだただ のコーヒーだったんです。コーヒーを大量に飲 む方は時々いらっしゃるので気を付ける必要が あります．あと当院はアルコールの患者さんが 多いのですがアルコールの患者さんはほとんど 全員下痢をしています，小腸にもガスがいっぱ いあって, 人によっては拪を下剂代わりに使っ ているという女の人もいます.「IBS下痢型と思っ ている人の 3 割は飲酒が下痢の原因と考えてい た」というインターネット調査もありますので, 喏好品についてはしっかり聞いておいたほうが いいと思います。 
また，私自身の患者としての経験ですが，地 方の病院での過労・心労でFDのEPSとNERD になりました，研修医に練習台を兼ねて胃ファ イバースコープをやって貫ったのですが，当時 まだEPSとかNERDとか言われていない時代だっ たので，「胃袋に穴が空くかと思ってPPIをずっ と飲んでいた」と検査前に言っていた手前, 非 常にきれいな胃粘膜を見せられてショックで納 得がいきませんでした，後で振り返ると「こう いうきれいな胃袋だからこそ, そういう症状が 出る可能性がありますよ」と一言もらえると患 者の立場としてはすごく救われるかなと思いま した．現在私は腸が動いてしまって大腸鏡が入 れにくいとか，腸が念れて入れにくいとかいう 方は，逆に言うと便が出すぎて困るとか，便が 出にくいということにつながるのではないかと 考えているのですけれども，そのように説明し てあげることで，おそらく私が救われたであろ うと同じょうに，患者さんも救われるのではな いかなと思っています。

三浦私も，この間印象深い症例を経験しま した. 皆さん, 器質的疾患を注意しろとおっしゃ いますが，この方は器質的疾患がある中高年女 性の患者さんで, $1.5 \mathrm{~cm}$ ぐらいの膵囊胞性腫瘍 (膵管内乳頭粘液産生腫瘍)があり, 長年フォロー アップをしていたのですが, ある日,「お腹が痛 い」と言い始めました．「食後に痛い」とか, ずっ と痛い, 痛い, 痛いで, $2 \sim 3$ カ月以上続き, 胃 カメラで粗大病変は無く CT撮影で腫瘍の大きさ は全く変わらないのですが, CA19-9 值が少しづ つ右肩上がりに上がってきたのですね．外科の 先生にお願いして,「症状が強いので膵囊胞の手 術を考えようか」と相談をしていた訳です。し かし, 念のためにPPIを飲んでもらったら, その 瞬間に「よくなりました」と言って，手術を考 えなくてよかったという症例がありました.我々 も器質的疾患が刷り込まれているので, FDだと 気付くのが遅れてしまいました。器質的疾患が
ある方でも, 逆にFGIDが合併してくることもあ りえるということで勉強になりました.

\section{FGID研究の将来について}

三浦 最後に, 皆さんは専門家として, 現在 どのようなことに興味を持っておられるかをお 話しいただき,さらに将来, FGIDの研究や診療 が，どういう方向性に進むのかということをお 教えいただきたいと思います。では，鳥居先生 から.

鳥居いま，自分は 3 つほど課題を考えてい ます．まずひとつは，先ほどから言っている， 「消化管は 1 本の管」ということです. NERD, FD，IBS，は合併することが多いといわれてい ます，それから，合併することによりQOLも低 下するといわれています. 総合的にそれらの症 状とらえる質問用紙もいくつか出ています. NERD, FD, IBSは病態も類似しており,一つ一 つを個々の病気として見るのではなくて, 総合 的に捉え，患者のQOLを上げていくにはどうし たらいいかということを考えていきたいと思っ ています.

それからもうひとつは, 器質的疾患の除外の 面です.たとえばNERDの場合もFDの場合もIBS の場合も，いま内視鏡という手技がありますか ら，直接消化管を見ることができるわけです.

しかし，どこまでの病変を器質的疾患としてと らえるかが問題となります，たとえば, NERD に関しては，発赤や浮腫を表すミニマルチェン ジがあった場合はそれを器質的疾患と考えるか どうかということが問題になります。それによ り逆流性食道炎としてとらえるか, NERDとして とらえるのかが変わってくるわけです．日本で みる逆流性食道炎というのは，発赤や浮腫を主 体としたいわゆるミニマルチェンジで，欧米で はNERDに分類されると思われます.臨床の第一 線であるクリニックを訪れる症例は，ほとんど 
が発赤や浮腫，あるいは胃粘膜の湾入とか, Ultra short Barrett'sとかいう状態で, 実際にびら ん病変があるという人は本当に少ないといえま す. 内視鏡所見からすると, 厳密にはNERDであ り, そういう意味ではPPIのフルドースを使うこ とがいいのかどうかと考えてしまいます.ただ, フルドースを使えば，症状がより良くなる方が たくさんいるのも確かです.FDに関しても, 発 赤, 浮腫が幽門前庭部のところにあれば, 当然 それが排出能を落としている可能性があるわけ です．潰瘍病変はないわけですが，それをFD に入れるべきかどうか問題になります. IBSに関 しても, microscopic colitisのような, 直腸粘膜 に浮腫の所見があるものを, IBSとするか, 直腸 炎とするか, UCの初期像ととらえるか, 境界領 域的なものを今後，どう分類していくかという ことが問題になると思われます。欧米の分類で は, その混乱をさけるため, 粘膜欠損があるか どうかで仕切っているわけです. しかし, 発赤, 浮腫などの病変を認める場合は，それは症状の 原因となる器質的病変といえると思われます，

Non ulcerではあるけれども, 症状の原因となる 器質的病変ではないかと考えるわけです，機能 的疾患と器質的疾患の境界領域の検討が必要と 思われます。

それから 3 番目の課題は, FGIDの診断に有用 なバイオマーカーがないということです．いろ いろなことがやられていますけれども, 決め手 がないのが現状です.FGIDのバイオマーカーの ひとつとしては, ブレインイメージングあげら れます．脳腸相関の病態解明につながり，バイ オマーカーとしての可能性が期待されています. しかしこのブレインイメージングを一般臨床の 場で診断に利用することはかなり困難といえま す. 臨床的には, 水上先生が検討されているよ うな, 大腸鏡で簡便にIBSに特徵的な所見を認め, それがIBS診断におけるバイオマーカーになれば と期待しております. 血液検査やX検査で検討可
能な, より簡便で有効なバイオマーカーが将来 的にできてくれると臨床医としては助かるなと 思っております。

三浦 その通りだと思いますね. 二神先生は, いかがですか.

二神 私は, 2 つほど興味があることがありま して，ひとつは感染を契機にして生じる機能性 障害です. 感染後IBSとか, 感染後FDというよ うな疾患概念があるんですけれども，そのあた りに私としては興味がありまして, 感染の結果, 消化管の局所に炎症が生じるということで，そ の消化管の炎症と, それからそこの消化管の知 覚神経といいますか, 炎症と粘膜局所の神経と のインターラクションといいますか, いわゆる 炎症細胞浸潤を含めまして，そのあたりがどう なっていくのかなというのは，これからの消化 器病のテーマのひとつになるのではないかなと も思っておりますし, 非常に重要なところかな と思います。

もうひとつは, 先ほどバイオマーカーの話が 出ましたけれども, FDのなかでも, 特に現在の Rome IIIでいうPDSの方は, 食事に関わる臨床症 状なわけですが，そういう食事と関係するよう なホルモンですね. グレリンですとか, 脳内ぺ プタイドですとか, そういった, 先程来出てい ます脳腸相関といいますか, そういったものが どのように機能性疾患に関わっているのかと. そのあたりに非常に興味を持っております.

三浦 水上先生は, いかがですか.

水上 私は, 大腸鏡でIBSの病態を調べて, ス トレス（腸管運動）と関係あるのか, 腸管形態 が関係あるのかとか, 病態をターゲットにして 治療できるようにできたらいいなと思ってやっ ております。最近は苦痛が少ない新しい挿入法 が開発され, 先端が柔軟な大腸鏡が販売されて, 無麻酔でも痛くなく検査できるようになってき ました.これまでの大腸鏡は炎症とか腫瘍をター ゲットにして見ていたと思います。確かにそれ 
だと異常がなかったかもしれませんけど，新た に大腸鏡を腸管運動とか腸管形態というものに も観察範囲を広げた機能性腸疾患の評価・観察 ツールにすることができたらいいなと思ってい ます。

三浦 内視鏡下の運動や形態を見てというこ とですね.

水上 検查自体は痛くはないんですけど，ス トレステストにはなっていますので.

三浦 麻酔とかせずに, sedation（鎮静状態） なしでやってらっしゃるんですね.

水上 ええ. 私も 3 回ばかり被検者として無 麻酔で大腸鏡をやってもらいましたけど，今の 大腸鏡は本当に痛くないどころか何も感じませ ん．これから無麻酔大腸鏡を普及させて，これ まで内視鏡の観察対象は炎症と腫瘍だけでした けれども，新たに腸管運動や腸管形態など機能 性のものも評価できるものにして，欧米と違っ て日本人の難しい腸で内視鏡医はみんな苦労し ているわけですから，あわよくば点数をアップ していただきたいなと思っています.

三浦 そろそろ時間になって参りましたが， 何かございましたら追加発言をお願いしたいと 思います。

鳥居 私も感染後のIBS, FDという病態には 非常に興味を持っております.現在IBSの方には 便の細菌培養検査を全員の方に施行しておりま す。これは肚門から綿棒を入れ，検体を採取す る方法です。その結果， $30 \%$ 前後の方で病原菌 が検出されます．多くは病原性大腸菌ですが, 他にもいくつかの病原菌が検出されています. おそらくこれはpost-infectious IBSなのか, bac- terial overgrowthなのか, まだ不明な点が多いわ けですが，何らか病態が関連していると考えて おります。アメリカでは非吸収性の抗生剂を投 与し, IBSの治療を試みております。しかし病原 菌を除菌したからといっても必ずしもIBSの症状 が改善するとは限りません. またイリボー ${ }^{\circledR} と と ゙$ を除菌に先行して投与すれば，病原菌がいても 症状は改善します。これらの病原菌がどれだけ 病態に関与しているのかは, 非常に興味深く思っ ております。

三浦 そういう感染後のIBSというのは,もう 少し検討していく必要がありますね.

FGIDへの関心や認識の高まりにより,科学的 なEBMに基づく診断・治療のアプローチが行わ れるようになりました。また，新薬の治療開発 も非常に進んでおり，FGIDは現在，非常にホッ トな分野として注目を浴びています。皆さんの お話を伺いますと，やはり今後は，何か器質的 なマイナーなinflammation (炎症)の存在や, 中 枢神経系のサーキットの異常とか, 多角的に研 究が進んで, 何か画期的な発見が生まれるので はという予感も致します。また先ほど紹介があ りましたけれども，ようやく日本人のためのプ ラクティカルなガイドラインが整備されつつあ り，更に一段と診療面の進歩が見られると期待 されます．先生方もその進歩に大いに貢献して いただきたいと思います，有益なお話をありが とうございました

著者のCOI (conflicts of interest) 開示 : 本論文発表内容に 関連して特に申告なし 